\title{
ON SUPER EDGE-ANTIMAGIC TOTAL LABELING OF SUBDIVIDED STARS ${ }^{1}$
}

\author{
MuHAmmad JaVAID \\ Department of Mathematics \\ National University of Computer and \\ Emerging Sciences, Lahore Campus, Pakistan \\ e-mail: mjavaidmath@gmail.com \\ javaidmath@gmail.com
}

\begin{abstract}
In 1980, Enomoto et al. proposed the conjecture that every tree is a super $(a, 0)$-edge-antimagic total graph. In this paper, we give a partial support for the correctness of this conjecture by formulating some super $(a, d)$ edge-antimagic total labelings on a subclass of subdivided stars denoted by $T\left(n, n+1,2 n+1,4 n+2, n_{5}, n_{6}, \ldots, n_{r}\right)$ for different values of the edgeantimagic labeling parameter $d$, where $n \geq 3$ is odd, $n_{m}=2^{m-4}(4 n+1)+1$, $r \geq 5$ and $5 \leq m \leq r$.
\end{abstract}

Keywords: super $(a, d)$-EAT labeling, subdivision of star.

2010 Mathematics Subject Classification: 05C78.

\section{REFERENCES}

[1] M. Bača, Y. Lin, M. Miller and M.Z. Youssef, Edge-antimagic graphs, Discrete Math. 307 (2007) 1232-1244. doi:10.1016/j.disc.2005.10.038

[2] M. Bača, Y. Lin, M. Miller and R. Simanjuntak, New constructions of magic and antimagic graph labelings, Util. Math. 60 (2001) 229-239.

[3] M. Bača, Y. Lin and F.A. Muntaner-Batle, Super edge-antimagic labelings of the path-like trees, Util. Math. 73 (2007) 117-128.

[4] M. Bača and M. Miller, Super Edge-Antimagic Graphs (Brown Walker Press, Boca Raton, Florida USA, 2008).

\footnotetext{
${ }^{1}$ The research contents of this paper are partially supported by the Higher Education Commission (HEC) of Pakistan.
} 
[5] H. Enomoto, A.S. Lladó, T. Nakamigawa and G. Ringel, Super edge-magic graphs, SUT J. Math. 34 (1998) 105-109.

[6] J.A. Gallian, A dynamic survey of graph labeling, Electron. J. Combin. (2011) \#DS6.

[7] M. Hussain, E.T. Baskoro and Slamin, On super edge-magic total labeling of banana trees, Util. Math. 79 (2009) 243-251.

[8] M. Javaid, M. Hussain, K. Ali and H. Shaker, On super edge-magic total labeling on subdivision of trees, Util. Math. 89 (2012) 169-177.

[9] M. Javaid and A.A. Bhatti, On super $(a, d)$-edge antimagic total labeling of subdivided stars, Ars Combin. 105 (2012) 503-512.

[10] M. Javaid, A.A. Bhatti and M. Hussain, On $(a, d)$-edge-antimagic total labeling of extended w-trees, Util. Math. 87 (2012) 293-303.

[11] M. Javaid, M. Hussain, K. Ali and K.H. Dar, Super edge-magic total labeling on w-trees, Util. Math. 86 (2011) 183-191.

[12] M. Javaid, A.A. Bhatti, M. Hussain and K. Ali, Super edge-magic total labeling on forest of extended w-trees, Util. Math. 91 (2013) 155-162.

[13] A. Kotzig and A. Rosa, Magic valuations of finite graphs, Canad. Math. Bull. 13 (1970) 451-461. doi:10.4153/CMB-1970-084-1

[14] A. Kotzig and A. Rosa, Magic Valuation of Complete Graphs (Centre de Recherches Mathematiques, Uni. de Montreal, 1972).

[15] S.M. Lee and Q.X. Shah, All trees with at most 17 vertices are super edge-magic, in: 16th MCCCC Conference, Carbondale SIU (2002).

[16] Y.-J. Lu, A proof of three-path trees $P(m, n, t)$ being edge-magic, College Mathematica 17(2) (2001) 41-44.

[17] Y.-J. Lu, A proof of three-path trees $P(m, n, t)$ being edge-magic (II), College Mathematica 20(3) (2004) 51-53.

[18] A.A.G. Ngurah, R. Simanjuntak and E.T. Baskoro, On (super) edge-magic total labeling of subdivision of $K_{1,3}$, SUT J. Math. 43 (2007) 127-136.

[19] A.N.M. Salman, A.A.G. Ngurah and N. Izzati, On super edge-magic total labeling of a subdivision of a star $S_{n}$, Util. Math. 81 (2010) 275-284.

[20] K.A. Sugeng, M. Miller, Slamin and M. Bača, $(a, d)$-edge-antimagic total labelings of caterpillars, Lect. Notes Comput. Sci. 3330 (2005) 169-180. doi:10.1007/978-3-540-30540-8_19

[21] R. Simanjuntak, F. Bertault and M. Miller, Two new $(a, d)$-antimagic graph labelings, in: Proc. 11th Australian Workshop on Combin. Algor. 11 (2000) 179-189.

[22] D.B. West, An Introduction to Graph Theory (Prentice Hall, 1996).

Received 11 June 2012

Revised 2 October 2013

Accepted 2 October 2013 